\title{
Analisis Kestabilan dan Travelling Wave pada Model Penyebaran Virus Ebola
}

\author{
${ }^{1}$ MNH Qomarudin, ${ }^{2}$ ADSC Metyana, ${ }^{3}$ YN Afifah \\ ${ }^{1,2}$ Universitas Nahdlatul Ulama Blitar, Indonesia \\ ${ }^{3}$ Universitas Maarif Hasyim Latief, Indonesia
}

Email: 1'nurhaqqul@unublitar.ac.id, ${ }^{2}$ Adwi77670@gmail.com,

3yunita@dosen.umaha.ac.id

\section{Tersedia Online di \\ http://www.jurnal.unublitar.ac.id/i ndex.php/briliant}

\begin{tabular}{l}
\hline Sejarah Artikel \\
\hline Diterima pada 11 Februari 2020 \\
Disetujui pada 11 Maret 2020 \\
Dipublikasikan pada 30 Mei 2020 \\
Hal. 369-383 \\
\hline
\end{tabular}

\begin{tabular}{l}
\hline Kata Kunci: \\
\hline Virus Ebola; Model SEIR; \\
Travelling Wave \\
\hline \\
\hline DOI: \\
\hline http://dx.doi.org/10.28926/briliant. \\
v3i4.441 \\
\hline
\end{tabular}

\begin{abstract}
Abstrak: Virus Ebola disebabkan oleh infeksi virus Ebola yang disebut Ebola Virus Disease (EVD). Virus Ebola merupakan virus yang masuk kedalam family Filoviridae. Penyebaran Virus Ebola terjadi karena kontak langsung antar individu melalui kulit yang rusak atau membran selaput lendir atau objek seperti jarum. Sedangkan objek penularannya yaitu cairan tubuh yang terinfeksi. Penyebaran penyakit Ebola selanjutnya diamati menggunakan model matematika SEIR yang terdiri atas empat variable states yang berbeda. Dalam hal ini pengamatan mengenai kestabilan model tersebut dilakukan guna mengetahui tingkah laku sistem agar lebih mudah memahami mengenai penyakit tersebut. Selanjutnya pengamatan tingkah laku sistem dilakukan dengan mengkonstruksikan model travelling wave sedemikian hingga didapatkan kecepatan minimum $c_{I}$ dan $c_{E}$ yang dibutuhkan agar terjadi gelombang penyebaran penyakit
\end{abstract} tersebut. Pada tahap terakhir isimulasi dilakukan menggunakan Matlab agar data tersebut lebih mudah dilihat, dibaca dan, dipahami. Dalam hal ini, model matematika ini dapat menjadi bahan pertimbangan atas tindakan pencegahan penyakit yang disebabkan oleh virus Ebola.

\section{PENDAHULUAN}

Perkembangan dan kemajuan dalam bidang ilmu pengetahuan dan teknologi (IPTEK) saat ini tidak bisa dipisahkan dari matematika salah satunya yaitu model matematika. Model matematika merupakan salah satu alat yang dapat mempermudah penyelesaian masalah dalam kehidupan nyata. Adapun contohnya yaitu aplikasi untuk mengetahui model penyebaran penyakit menular pada suatu daerah atau wilayah tertentu. Untuk mengetahui penyebaran penyakit menular, dikenal beberapa model penyebaran penyakit. Model penyebaran penyakit memiliki karakteristik sendiri berdasarkan jenis dan bentuk yang diamati, misalnya model SEIR pada penyakit Ebola (Hasrina, 2015).

Penyakit Ebola disebabkan oleh infeksi virus Ebola yang disebut Ebola Virus Disease (EVD). Virus Ebola termasuk famili Filoviridae. Ebola pertama kali dikenal pada tahun 1976 ketika 2 penyebaran yang terjadi di Sudan Selatan dan Republik Demokrat Kongo, tepatnya di sebuah desa yang berdekatan dengan Sungai Ebola, yang merupakan asal nama penyakit ini. Termasuk dengan 
epidemik saat ini, telah ada kira-kira 280 penyebaran Ebola yang dikenali dengan tingkat kematian 25\% hingga 90\% (Meyers et al, 2015).

Penyebaran Virus Ebola terjadi karena kontak langsung antar individu melalui kulit yang rusak atau membran selaput lendir atau objek seperti jarum. Sedangkan objek penularannya yaitu cairan tubuh yang terinfeksi. Cairan tubuh tersebut antara lain air liur, darah, muntahan, diare, dan air mani. Secara umum Ebola tidak menyebar melalui udara. Jadi, sebagai perbandingan, penularannya tidak seperti campak atau influenza (Meyers et al, 2015). Berdasarkan penjelasan singkat mengenai fakta-fakta tentang penyakit akibat virus Ebola di atas dan berbahaya terhadap umat manusia, maka sangat perlu untuk mempelajarinya. Salah satunya dengan pemodelan matematika penyebaran penyakit Ebola. Model matematika yang digunakan dalam artikel ini adalah model SEIR.

Terdapat beberapa artikel terdahulu mengenai pemodelan matematika yang dijadikan acuan pada artikel ini, diantaranya adalah: (1) solusi numerik model umum epidemik Susceptible, Infected, Recovered (SIR) dengan menggunakan metode Modified Milne-Simpson (Wahyudin Nur, Nurul Mukhlisah Abdal, 2016). (2) pemodelan matematika penyebaran penyakit ebola dengan model epidemi SIR pada populasi manusia tak konstan dengan treatment (Adhitya Himawan, S. Budi Waluya, dan Supriyono, 2017), (3) a numerical study of SIR epidemic model (N. Kousar, R. Mahmood, M. Ghalib), (4) solusi numerik model SIR pada penyebaran penyakit tuberkulosis dengan metode Runge-Kutta (Syafruddin Side, Sukarna, dan Arli Maghfirah Utami), analisis kestabilan model penyebaran virus ebola (Nok Muntoyimah, Widowati, YD. Sumanto).

Pada penulisan ini akan dilakukan pengamatan tingkah laku model SEIR yang diperoleh. Seperti yang dilakukan oleh Haqqul, M. N. dkk 2017, penulis melakukan analisis kestabilan pada model guna memahami tingkah laku yang terjadi pada model. Selanjutnya model travelling wave akan dikonstruksi dan di analisis guna mendapatkan kecepatan minimum yang dibutuhkan agar terjadi penyebaran penyakit. Selanjutnya simulasi numerik dilakukan pada model SEIR menggunakan software matlab agar lebih mudah memahami model tersebut.

\section{Model Penyebaran Virus Ebola}

Bagian ini menyajikan secara ringkas tentang bagaimana penelitian dilakukan. Uraian disajikan dalam beberapa paragraf tanpa subbagian atau dipilah-pilah dalam subsubbagian. Isinya, menyangkut teknik pengumpulan data, subjek/sampel, instrumen pengumpulan data, sumber data, dan teknik analisis data. Kutipan ahli tentang metode penelitian diperbolehkan untuk ditulis. Agar menghindari penggunaan tabel, dan lebih mengutamakan penulisan dalam bentuk deskriptif.

Model matematika memiliki peranan yang penting dalam menganalisa suatu fenomena epidemik dalam bidang kesehatan dengan mengetahui tingkat penyebaran virus pada penyakit menular. Dalam dinamika penyebaran epidemik terdapat suatu kontak antara individu yang sehat namun rentan terhadap virus dengan individu yang terinfeksi virus sehingga digunakan model endemik dalam menganalisa penyebaran virus Ebola.

Model matematika SEIR dapat dinyatakan kedalam sistem persamaan diferensial biasa yang dapat dituliskan sebagai berikut:

370 BRILIANT: Jurnal Riset dan Konseptual Volume 5 Nomor 2, Mei 2020 
$S^{\prime}=A-\beta S I-\mu S$,

$E^{\prime}=\beta S I-\gamma E$,

$I^{\prime}=\gamma E-\delta I$,

$R^{\prime}=\delta I-\mu R$,

Dimana dalam hal ini berlaku:

$S(0), E(0), I(0), R(0) \geq 0$

Parameter yang digunakan pada model ini adalah $A$ menyatakan laju pertambahan populasi baru yang diasumsikan sebagai individu sehat, $\mu$ menyatakan laju kematian alami yang mungkin terjadi pada populasi, $\beta$ menyatakan laju kontak efektif antara individu yang rentan dan infeksi, $\gamma$ menyatakan laju infeksi per kapita, dan $\delta$ menyatakan laju kematian atau pemulihan individu yang teinfeksi.

Jumlah individu pada kelas susceptible (S) menurun akibat penularan penyakit $(\beta S I)$ dan kematian alami $(\mu S)$. Jumlah individu pada kelas exposed $(\mathrm{E})$ terjadi penambahan $(\beta S I)$ dan menurun akibat bertambahnya jumlah individu pada kelas $(E)$ yang memasuki kelas (I) yang dinyatakan sebagai $(\gamma E)$. Dalam hal ini jumlah inidividu pada kelas $(I)$ juga berkurang sebesar $(\delta I)$ yang menyebabkan bertambahnya Jumlah individu pada kelas recovered (R) sebesar $(\delta I)$ dikarenakan individu terinfeksi yang mengalami proses pengobatan. Kemudian jumlah individu yang sehat akibat penyakit dinyatakan sebagai $(\mu R)$ yang mengakibatkan penurunan jumlah individu pada kelas $(R)$ (Adhitya Himawan, S. Budi Waluya, dan Supriyono, 2017).

\section{Titik Kesetimbangan}

\section{Teorema 1}

Jika diambil $R_{0}=\frac{\beta A}{\mu \delta}$ maka diperoleh

Dua titik kesetimbangan pada sistem (1) yaitu $E_{0}=(S, E, I, R)=\left(\frac{A}{\mu}, 0,0,0\right)$ dan $E^{*}=\left(S^{*}, E^{*}, I^{*}, R^{*}\right)=\left(\frac{\delta}{\beta}, \frac{\beta A-\mu \delta}{\beta y}, \frac{\beta A-\mu \delta}{\beta \delta}, \frac{\beta A-\mu \delta}{\beta \mu}\right)$.

\section{Bukti:}

Untuk mendapatkan titik kesetimbangan, maka masing-masing ruas kanan persamaan dari sistem (1) dibuat sama dengan nol, sehingga akan diperoleh

$A-\beta S I-\mu S=0$,

$\beta S I-\gamma E=0$,

$\gamma E-\delta I=0$,

$\delta I-\mu R=0$,

Dari $\beta S I-\gamma E=0$ diperoleh:

$\Leftrightarrow E=\frac{\beta S I}{\gamma}$

Substitusi $E=\frac{\beta S I}{\gamma}$ kedalam $\gamma E-\delta I=0$ diperoleh: 
$\gamma\left(\frac{\beta S I}{\gamma}\right)-\delta I=0$

Sehingga didapatkan $I=0$ atau dan $S=\frac{\delta}{\beta}$

1) Kasus $I=0$.

Misal titik kesetimbangan bebas penyakit adalah $E_{0}=\left(S_{0}, E_{0}, I_{0}, R_{0}\right)$.

a) Substitusi $I=0 \mathrm{ke} A-\beta S I-\mu S=0$ diperoleh $S=\frac{A}{\mu}$.

b) Substitusi $I=0 \mathrm{ke} \beta S I-\gamma E=0$ diperoleh $E=0$.

c) Substitusi $I=0$ ke $\delta I-\mu R=0$ diperoleh $R=0$.

Sehingga titik kesetimbangan yang pertama dapat dinyatakan sebagai berikut

$E_{0}=\left(S_{0}, E_{0}, I_{0}, R_{0}\right)=\left(\frac{A}{\mu}, 0,0,0\right)$.

2) Kasus $I \neq 0$ dimana Jelas $S^{*}=\frac{\delta}{\beta}$.

Jika diberikan titik kesetimbangan endemik adalah $E^{*}=\left(S^{*}, E^{*}, I^{*}, R^{*}\right)$.

Sedemikian hingga dapat diperoleh

$A-\beta S^{*} I^{*}-\mu S^{*}=0$,

$\beta S^{*} I^{*}-\gamma E^{*}=0$,

$\gamma E^{*}-\delta I^{*}=0$,

$\delta I^{*}-\mu R^{*}=0$,

$N^{*}=S^{*}+E^{*}+I^{*}+R^{*}$.

a) Substitusi $S^{*}=\frac{\delta}{\beta}$ ke $A-\beta S^{*} I^{*}-\mu S^{*}=0$

Diperoleh $I^{*}=\frac{\beta A-\mu \bar{\delta}}{\beta \delta}$.

b) Substitusi $I^{*}=\frac{\beta A-\mu \delta}{\beta \delta}$ ke $\gamma E^{*}-\delta I^{*}=0$ diperoleh $E^{*}=\frac{\beta A-\mu \delta}{\beta y}$.

c) Substitusi $I^{*}=\frac{\beta A-\mu \delta}{\beta \delta}$ ke $\delta I^{*}-\mu R^{*}=0$ Diperoleh $R^{*}=\frac{\beta A-\mu \delta}{\beta_{\mu}}$.

Jadi, $E^{*}=\left(S^{*}, E^{*}, I^{*}, R^{*}\right)=\left(\frac{\delta}{\beta}, \frac{\beta A-\mu \delta}{\beta y}, \frac{\beta A-\mu \delta}{\beta \delta}, \frac{\beta A-\mu \delta}{\beta \mu}\right)$.

Jelas jika $\beta A-\mu \delta \geq 0$, maka semua suku $E^{*}$ bernilai tak negatif.

Untuk menentukan angka rasio reproduksi dasar $\left(R_{0}\right)$ dengan mengasumsikan $I^{*}>0$, berdasarkan $E^{*}$ diperoleh:

$I^{*}=\frac{\beta A-\mu \delta}{\beta \delta}$ sedemikian hingga $\frac{\beta A}{\mu \delta}>1$.

Didefinisikan $R_{0}=\frac{\beta A}{\mu \delta}$.

Diambil $R_{0}=\frac{\beta A}{\mu \delta}$.

\section{Kestabilan pada Model Virus Ebola}

\section{Teorema 2:}

Jika diberikan bilangan reporduksi dasar $R_{0}=\frac{\beta A}{\mu \delta}, E_{0}$, dan $E^{*}$ adalah titik-titik kesetimbangan sistem (1) seperti pada teorema (1).

Berdasarkan $R_{0}$ diperoleh:

1. Jika $R_{0}<1\left(0 \leq R_{0}<1\right)$ maka $E_{0}$ stabil asimtotik lokal.

2. Jika $R_{0}>1$ maka $E_{0}$ tidak stabil dan $E^{*}$ stabil asimtotik lokal. 


\section{Bukti:}

Analisis kestabilan ditentukan berdasarkan nilai eigen dari matriks jacobian yang diperoleh melalui metode linearisasi. Matriks jacobian dari sistem adalah sebagai berikut.

$I^{*}(E)=\left(\begin{array}{cccc}\frac{\partial S^{r}}{\partial S} & \frac{\partial S^{r}}{\partial E} & \frac{\partial S^{r}}{\partial I} & \frac{\partial S^{r}}{\partial R} \\ \frac{\partial E^{r}}{\partial S} & \frac{\partial E^{r}}{\partial E} & \frac{\partial E^{r}}{\partial I} & \frac{\partial E^{r}}{\partial R} \\ \frac{\partial I^{r}}{\partial S} & \frac{\partial I^{r}}{\partial E} & \frac{\partial I^{r}}{\partial I} & \frac{\partial I^{r}}{\partial R} \\ \frac{\partial R^{r}}{\partial S} & \frac{\partial R^{r}}{\partial E} & \frac{\partial R^{r}}{\partial I} & \frac{\partial R^{r}}{\partial R}\end{array}\right)$
$\Leftrightarrow J^{*}(E)=\left(\begin{array}{cccc}-\beta I-\mu & 0 & -\beta S & 0 \\ \beta I & -\gamma & \beta S & 0 \\ 0 & \gamma & -\delta & 0 \\ 0 & 0 & \delta & -\mu\end{array}\right)$

dengan $E=(S, E, I, R)$.

\section{Analisis kestabilan di sekitar titik kesetimbangan bebas penyakit}

Untuk melakukan analisis kesetimbangan pada model, dalam hal ini akan dicari nilai eigen untuk titik tetap $E_{0}$ dan $E^{*}$.

Untuk titip tetap yang pertama dalam hal ini $E_{0}=\left(\frac{A}{\mu}, 0,0,0\right)$ sedemikian hingga diperoleh diperoleh:

$I^{*}\left(E_{0}\right)=\left(\begin{array}{cccc}-\mu & 0 & \frac{-\beta A}{\mu} & 0 \\ 0 & -\gamma & \frac{\beta A}{\mu} & 0 \\ 0 & \gamma & -\delta & 0 \\ 0 & 0 & \delta & -\mu\end{array}\right)$.

Selanjutnya dicari nilai eigen dengan $\operatorname{det}\left(\lambda I-J^{*}\right)=0$ sedemikian hingga diperoleh

$\operatorname{det}\left(\begin{array}{cccc}\lambda+\mu & 0 & \frac{-\beta A}{\mu} & 0 \\ 0 & \lambda+\gamma & \frac{\beta A}{\mu} & 0 \\ 0 & \gamma & \lambda+\delta & 0 \\ 0 & 0 & \delta & \lambda+\mu\end{array}\right)=0$

Dengan menghitung persamaan tersebut dapat diperoleh:

$(\lambda+\mu)\left|\begin{array}{ccc}\lambda+\gamma & \frac{-\beta A}{\mu} & 0 \\ -\gamma & \lambda+\delta & 0 \\ 0 & -\delta & \lambda+\mu\end{array}\right|=0$

Sedemikian hingga $\lambda_{1}=-\mu, \lambda_{2}=-\mu$. Dalam hal ini jelas bahwa nilai-nilai eigen tersebut bernilai negatif. Selanjutnya untuk mencari nilai eigen $\lambda_{3}$, dan $\lambda_{4}$ maka perhitungan dilakukan pada persamaan

$$
\left[\{(\lambda+\gamma)(\lambda+\delta)\}-\left\{\left(\frac{-\beta A}{\mu}\right)(-\gamma)\right\}\right]=0
$$


$\Leftrightarrow \lambda^{2}+(\gamma+\delta) \lambda+\gamma \delta-\frac{\beta \gamma A}{\mu}=0$

karena $R_{0}=\frac{\beta A}{\mu \delta}$

$\Leftrightarrow \beta=\frac{R_{\mathrm{0}} \mu \delta}{A}$, maka:

$\lambda^{2}+(\gamma+\delta) \lambda+\gamma \delta-\frac{\beta \gamma A}{\mu}=0$

$\Leftrightarrow \lambda^{2}+(\gamma+\delta) \lambda+\gamma \delta-\frac{\frac{R_{0} \mu \tilde{E}}{A} \gamma A}{\mu}=0$

$\Leftrightarrow \lambda^{2}+(\gamma+\delta) \lambda+\gamma \delta-R_{0} \delta \gamma=0$

$\Leftrightarrow \lambda^{2}+(\gamma+\delta) \lambda+\gamma \delta\left(1-R_{0}\right)=0$

Dalam hal ini dengan menyelesaikan persamaan tersebut maka dapat diperoleh

$\lambda_{3_{i} 4}=\frac{-(\gamma+\delta) \pm \sqrt{(\gamma+\delta)^{2}-4 \gamma \delta\left(1-R_{0}\right)}}{2}$

Dalam hal ini dapat diambil $D=(\gamma+\delta)^{2}-4 \gamma \delta\left(1-R_{0}\right)$ sehingga diperoleh beberapa kasus sebagai berikut:

- Kasus $D<0$.

$D<0$ apabila $(\gamma+\delta)^{2}<4 \gamma \delta\left(1-R_{0}\right)$. Jelas $\lambda_{3_{3} 4}$ mempunyai bagian real negatif.

- $\operatorname{Kasus} D>0$.

$D>0$ apabila $(\gamma+\delta)^{2}>4 \gamma \delta\left(1-R_{0}\right)$.

Jelas $D<(\gamma+\delta)^{2}$

$\Leftrightarrow \sqrt{D}<\gamma+\delta$

$\Leftrightarrow \sqrt{D}-(\gamma+\delta)<0$

$\Leftrightarrow \frac{-(\gamma+\delta) \pm \sqrt{D}}{2}<0$.

Jika diambil nilai $\gamma \delta\left(1-R_{0}\right)>0$ sedemikian hingga diperoleh $R_{0}<1$ maka nilai $\lambda_{3,4}$ bernilai negatif.

Jadi dapat disimpulkan $\lambda_{1}<0, \lambda_{2}<0, \lambda_{3}<0, \lambda_{4}<0$, apabila $R_{0}<1$. Jadi, $E_{0}$ stabil asimtotik lokal.

\section{Analisis kestabilan di sekitar titik kesetimbangan endemik}

Untuk titik kesetimbangan endemik

$E^{*}=\left(S^{*}, E^{*}, I^{*}, R^{*}\right)=\left(\frac{\delta}{\beta}, \frac{\beta A-\mu \delta}{\beta y}, \frac{\beta A-\mu \delta}{\beta \delta}, \frac{\beta A-\mu \delta}{\beta \mu}\right)$, diperoleh:

$I^{*}\left(E^{*}\right)=\left(\begin{array}{cccc}-\beta I^{*}-\mu & 0 & -\beta S^{*} & 0 \\ \beta I^{*} & -\gamma & \beta S^{*} & 0 \\ 0 & \gamma & -\delta & 0 \\ 0 & 0 & \delta & -\mu\end{array}\right)$.

Selanjutnya dicari nilai eigen dengan $\operatorname{det}\left(\lambda I-J^{*}\right)=0$ sedemikian hingga diperoleh

$$
\left|\begin{array}{cccc}
\lambda+\beta I^{*}+\mu & 0 & \beta S^{*} & 0 \\
-\beta I^{*} & \lambda+\gamma & -\beta S^{*} & 0 \\
0 & \gamma & \lambda+\delta & 0 \\
0 & 0 & \delta & \lambda+\mu
\end{array}\right|=0
$$

Perhitungan dilakukan pada persamaan tersebut sedemikian hingga diperoleh 
$(\lambda+\mu)\left|\begin{array}{ccc}\lambda+\beta I^{*}+\mu & 0 & \beta S^{*} \\ -\beta I^{*} & \lambda+\gamma & -\beta S^{*} \\ 0 & \gamma & \lambda+\delta\end{array}\right|=0$

Jadi diperoleh nilai eigen sebagai berikut:

$\lambda_{1}=-\mu$. Berdasarkan nilai-nilai eigen tersebut terlihat bahwa eigen $\lambda_{1}$ negatif. Selanjutnya $\lambda_{2}, \lambda_{3}$, dan $\lambda_{4}$ sedemikian hingga diperoleh dari persamaan sebagai berikut:

$\left[\left\{\left(\lambda+\beta I^{*}+\mu\right)(\lambda+\gamma)(\lambda+\delta)\right\}+\left\{\left(-\beta^{2} S^{*} I^{*} \gamma\right)\right\}-\left\{\left(\lambda+\beta I^{*}+\mu\right)\left(-\beta S^{*} \gamma\right)\right\}\right]=$ 0

Sehingga diperoleh

$$
\begin{aligned}
& {\left[\left\{\left(\lambda+\beta I^{*}+\mu\right)(\lambda+\gamma)(\lambda+\delta)\right\}+\left\{\left(-\beta^{2} S^{*} I^{*} \gamma\right)\right\}-\left\{\left(-\beta S^{*} \gamma \lambda-\beta^{2} S^{*} I^{*} \gamma-\right.\right.\right.} \\
& \left.\left.\left.\beta S^{*} \gamma \mu\right)\right\}\right]=0 \\
& \Leftrightarrow\left[\left\{\left(\lambda+\beta I^{*}+\mu\right)(\lambda+\gamma)(\lambda+\delta)\right\}+\left\{\left(\beta S^{*} \gamma \lambda+\beta S^{*} \gamma \mu\right)\right\}\right]=0 \\
& \Leftrightarrow\left[\left\{\left(\lambda+\beta I^{*}+\mu\right)(\lambda+\gamma)(\lambda+\delta)\right\}+\left\{\beta S^{*} \gamma(\lambda+\mu)\right\}\right]=0 \\
& \text { karena } S^{*}=\frac{\delta}{\beta}, \text { maka } \\
& {\left[\left\{\left(\lambda+\beta I^{*}+\mu\right)(\lambda+\gamma)(\lambda+\delta)\right\}+\left\{\beta \frac{\delta}{\beta} \gamma(\lambda+\mu)\right\}\right]=0} \\
& \Leftrightarrow\left[\left\{\left(\lambda+\beta I^{*}+\mu\right)(\lambda+\gamma)(\lambda+\delta)\right\}+\{\delta \gamma(\lambda+\mu)\}\right]=0
\end{aligned}
$$

Dimana $I^{*}=\frac{\beta A-\mu \delta}{\beta \delta}$, sehingga

$$
\begin{aligned}
& {\left[\left\{\left(\lambda+\beta \frac{\beta A-\mu \delta}{\beta \delta}+\mu\right)(\lambda+\gamma)(\lambda+\delta)\right\}+\{\delta \gamma(\lambda+\mu)\}\right]=0} \\
& \Leftrightarrow\left[\left\{\left(\lambda+\frac{\beta A-\mu \delta}{\delta}+\mu\right)(\lambda+\gamma)(\lambda+\delta)\right\}+\{\delta \gamma(\lambda+\mu)\}\right]=0 \\
& \Leftrightarrow\left[\left\{\left(\frac{\lambda \delta+\beta A-\mu \delta+\mu \delta}{\delta}\right)(\lambda+\gamma)(\lambda+\delta)\right\}+\{\delta \gamma(\lambda+\mu)\}\right]=0 \\
& \Leftrightarrow\left[\left\{\left(\frac{\lambda \delta+\beta A}{\delta}\right)(\lambda+\gamma)(\lambda+\delta)\right\}+\{\delta \gamma(\lambda+\mu)\}\right]=0
\end{aligned}
$$

karena $R_{0}=\frac{\beta A}{\mu \delta} \Leftrightarrow \beta=\frac{R_{0} \mu \delta}{A}$, maka:

$$
\begin{aligned}
& \Leftrightarrow\left[\left\{\left(\frac{\lambda \delta+\frac{R_{0} \mu \delta}{A} A}{\delta}\right)(\lambda+\gamma)(\lambda+\delta)\right\}+\{\delta \gamma(\lambda+\mu)\}\right]=0 \\
& \Leftrightarrow\left[\left\{\left(\frac{\lambda \delta+R_{0} \mu \delta}{\delta}\right)(\lambda+\gamma)(\lambda+\delta)\right\}+\{\delta \gamma(\lambda+\mu)\}\right]=0 \\
& \Leftrightarrow\left[\left\{\left(\lambda+R_{0} \mu\right)(\lambda+\gamma)(\lambda+\delta)\right\}+\{\delta \gamma(\lambda+\mu)\}\right]=0
\end{aligned}
$$


$\Leftrightarrow\left[\left\{\left(\lambda^{2}+\left(R_{0} \mu+\gamma\right) \lambda+R_{0} \mu \gamma\right)(\lambda+\delta)\right\}+\{\delta \gamma(\lambda+\mu)\}\right]=0$

$\Leftrightarrow\left[\left\{\left(\lambda^{3}+\left(R_{0} \mu+\gamma+\delta\right) \lambda^{2}+\left(R_{0} \mu \delta+\gamma \delta+R_{0} \mu \gamma\right) \lambda+R_{0} \mu \gamma \delta\right)\right\}+\right.$ $\{(\delta \gamma \lambda+\delta \gamma \mu)\}]=0$

$\Leftrightarrow\left[\left\{\left(\lambda^{3}+\left(R_{0} \mu+\gamma+\delta\right) \lambda^{2}+\left(R_{0} \mu \delta+2 \gamma \delta+R_{0} \mu \gamma\right) \lambda+\left(R_{0}+1\right) \mu \gamma \delta\right)\right\}\right]=0$

\section{Teorema 3}

Jika diberikan $d_{1}=\left(R_{0} \mu+\gamma+\delta\right), \quad d_{2}=\left(R_{0} \mu \delta+2 \gamma \delta+R_{0} \mu \gamma\right), \quad$ dan $d_{3}=\left(R_{0}+1\right) \mu \gamma \delta$ dengan $d_{i}>0$ untuk $i=1,2,3$ dan $R_{0}>1$ maka sistem (1) stabil asimptotik lokal.

Bukti:

Misalkan $\left(R_{0} \mu+\gamma+\delta\right)=d_{1},\left(R_{0} \mu \delta+2 \gamma \delta+R_{0} \mu \gamma\right)=d_{2},\left(R_{0}+1\right) \mu \gamma \delta=d_{3}$ $\Leftrightarrow\left[\left\{\left(\lambda^{3}+d_{1} \lambda^{2}+d_{2} \lambda+d_{3}\right)\right\}\right]=0$ dengan menggunakan kriteria Routh Hurwitz $\Leftrightarrow J_{3}=\left(\begin{array}{ccc}d_{2} & d_{3} & 0 \\ 1 & d_{1} & d_{2} \\ 0 & 0 & 1\end{array}\right)$

$\Leftrightarrow D_{1}=\operatorname{det}\left(J_{1}\right)=d_{2}>0$

$\Leftrightarrow D_{2}=\operatorname{det}\left(J_{2}\right)=\operatorname{det}\left(\begin{array}{cc}d_{2} & d_{3} \\ 1 & d_{1}\end{array}\right)=d_{1} d_{2}-d_{3}>0$

Sedemikian hingga diperoleh $d_{1} d_{2}>d_{3}$.

Selanjtunya sistem (1) tersebut stabil asimptotik lokal jika berlaku $d_{1} d_{2}>d_{3}$

Menurut teorema terlihat jelas bahwa $d_{1}>0, d_{2}>0, d_{3}>0$ dan $d_{1} d_{2}>d_{3}$ maka nilai eigen $\lambda_{2}, \lambda_{3}, \lambda_{4}$ bernilai real negatif.

Jadi $\lambda_{2,3,4}$ bernilai negatif.

Jelas $\lambda_{1}<0, \lambda_{2}<0, \lambda_{3}<0, \lambda_{4}<0$, apabila $R_{0}>1$. Jadi, $E^{*}$ stabil asimtotik lokal.

\section{Travelling Wave pada Model (1)}

Pada bagian ini akan dilakukan konstruksi model penyebaran virus ebola. Selanjutnya akan dilakukan analisa eksistensi travelling wave pada mdel penyebaran virus ebola dengan mendapatkan kecepatan minimal yang dibutuhkan agar terjadi penyebaraa.

Berdasarkan yang dilakukan oleh Haqqul, M.N dkk penyebaran terjadi akibat adanya infeksi yang terjadi pada individu exsposed dan terinfeksi. Maka langkah awal yang dilakukan yaitu dengan membentuk $L(u)$ dan $I(u)$ pada persamaan (1) dimana $u=x-c t$. Dalam hal ini $c$ adalah kecepatan minimal yang diperlukan agar terjadi suatu gelombang penyebaran. Oleh karena itu pada persamaan (1) akan diproleh persamaan sebagai berikut

$$
\begin{aligned}
& -c_{E} \frac{\partial E}{\partial u}=D_{E} \frac{\partial^{2} E}{\partial t^{2}}+\beta S I-\gamma E \\
& -c_{I} \frac{\partial I}{\partial u}=D_{I} \frac{\partial^{2} I}{\partial t^{2}}+\gamma E-\delta I
\end{aligned}
$$

Dengan syarat batas yang diambil pada persamaan (2) adalah sebagai berikut 


$$
\begin{aligned}
& \frac{\partial E(0)}{\partial t}=\frac{\partial E(\mathcal{L})}{\partial t}=0 \\
& \frac{\partial I(0)}{\partial t}=\frac{\partial I(\mathcal{L})}{\partial t}=0
\end{aligned}
$$

Dimana $D_{E}$ dan $D_{I}$ merupakan koefisien diffusifitas pada kompartemen $E$ dan $I$.

\section{Travelling wave disekitar $\left(\frac{A}{\mu}, 0,0,0\right)$}

Pada bagian ini dilakukan linearisasi pada model travelling wave persamaan (1) disekitar titik tetap bebas penyakit. Sehingga diperoleh persamaan sebagai berikut

$$
\begin{aligned}
& -c_{E} \frac{\partial E}{\partial u}=D_{E} \frac{\partial^{2} E}{\partial u^{2}}-\gamma E+\frac{\beta A}{\mu} I \\
& -c_{I} \frac{\partial I}{\partial u}=D_{I} \frac{\partial^{2} I}{\partial u^{2}}+\gamma E-\delta I
\end{aligned}
$$

Jika diberikan penyelesaia $(E, I)=\left(k_{1} e^{\omega u}, k_{2} e^{\omega u}\right)$ maka berdasarkan persamaan (3) dapat diperoleh

$-c_{E} \omega k_{1} e^{\omega u}=D_{E} \omega^{2} k_{1} e^{\omega u}-\gamma k_{1} e^{\omega u}+\frac{\beta A}{\mu} k_{2} e^{\omega u}$

$-c_{I} \omega k_{2} e^{\omega u}=D_{I} \omega^{2} k_{2} e^{\omega u}+\gamma k_{1} e^{\omega u}-\delta k_{2} e^{\omega u}$

Dimana $e^{\omega u} \neq 0$ sehingga dapat diperoleh

$$
\begin{aligned}
& f(\omega)=D_{E} \omega^{2} k_{1}+c_{E} \omega k_{1}-\gamma k_{1}+\frac{\beta A}{\mu} k_{2}=0 \\
& g(\omega)=D_{I} \omega^{2} k_{1}+c_{I} \omega k_{1}+\gamma k_{1}-\delta k_{2}=0
\end{aligned}
$$

Titik kritis pada persamaan (5) dapat diperoleh dengan memberikan $\frac{d f}{d \omega}=0$ sehingga $\omega_{E}=-\frac{C_{E}}{2 D_{E}}<0$ dan $\frac{d g}{d \omega}=0$ maka dapat diperoleh $\omega_{I}=-\frac{C_{I}}{2 D_{I}}<0$. Subsitusi nilai $\omega_{E}$ dan $\omega_{I}$ pada persamaan (5) sedemikian hingga diperoleh persamaan sebagai berikut

$$
\begin{aligned}
& k_{1} \frac{c_{E}^{2}}{4 D_{E}}-k_{1} \frac{c_{E}^{2}}{2 D_{E}}-\gamma k_{1}+\frac{\beta A}{\mu} k_{2}=0 \\
& k_{2} \frac{c_{I}^{2}}{4 D_{I}}-k_{2} \frac{c_{I}^{2}}{2 D_{I}}+\gamma k_{1}-\delta k_{2}=0
\end{aligned}
$$

Sehingga perhitungan yang dilakukan pada persamaan (6) memberikan kecepatan minimal yang dibutuhkan pada kompartemen $L$ dan $I$ agar terjadi gelombang penyebaran sebagai berikut

$$
c_{E}=2 \sqrt{\frac{D_{E}\left(\frac{\beta A}{\mu} k_{2}-\gamma k_{1}\right)}{k_{1}}}
$$




$$
c_{I}=2 \sqrt{\frac{D_{I}\left(\gamma k_{1}-\delta k_{2}\right)}{k_{2}}}
$$

Travelling wave disekitar $\left(S^{*}, E^{*}, I^{*}, R^{*}\right)$

Pada bagian ini untuk menganalisis eksistensi travelling wave disekitar titik kesetimbangan endemik, cara yang sama seperti pada saat analisis disekitar titik kesetimbangan bebas penyakit dapat digunakan. Dalam hal ini pelinearan pada pada persamaan (2) dengan titik kesetimbangan endemik dapat menghasilkan persamaan sebagai berikut

$$
\begin{aligned}
& -c_{E} \frac{\partial E}{\partial u}=D_{E} \frac{\partial^{2} E}{\partial u^{2}}+\beta I^{*} S-\gamma E+\beta S^{*} I \\
& -c_{I} \frac{\partial I}{\partial u}=D_{I} \frac{\partial^{2} I}{\partial u^{2}}+\gamma E-\delta I
\end{aligned}
$$

Pengamatan lebih lanjut dapat dilakukan pada $\beta I^{*} S$ dimana besaran tersebut menyatakan jumlah individu $S$ yang memasuki kelas exposed. Oleh karena itu nilai dari besaran tersebut dapat dituliskan sebagai $\beta I^{*} S=\sigma E$ sedemikian hingga persamaan (7) dapat dituliskan sebagai berikut

$$
\begin{aligned}
& -c_{E} \frac{\partial E}{\partial u}=D_{E} \frac{\partial^{2} E}{\partial u^{2}}+(\sigma-\gamma) E+\beta S^{*} I \\
& -c_{I} \frac{\partial I}{\partial u}=D_{I} \frac{\partial^{2} I}{\partial u^{2}}+\gamma E-\delta I
\end{aligned}
$$

Jika diambil penyelesaian dari persamaan (8) adalah $(E, I)=\left(k_{1} e^{\omega u}, k_{2} e^{\omega u}\right)$ maka dapat diperoleh

$$
\begin{aligned}
& f(\omega)=D_{E} \omega^{2} k_{1} e^{\omega u}+c_{E} \omega k_{1} e^{\omega u}+(\sigma-\gamma) k_{1} e^{\omega u}+\beta S^{*} k_{2} e^{\omega u}=0 \\
& g(\omega)=D_{I} \omega^{2} k_{2} e^{\omega u}+c_{I} \omega k_{2} e^{\omega u}+\gamma k_{1} e^{\omega u}-\delta k_{2} e^{\omega u}=0
\end{aligned}
$$

Dimana $e^{\omega u} \neq 0$. Dalam hal ini jika diambil $\frac{d f}{d \omega}=0$ dan $\frac{d g}{d \omega}=0$ maka pada masing-masing kompartemen pada persamaan (9) diperoleh $\omega_{E}=-\frac{C_{E}}{2 D_{E}}<0$ dan $\omega_{I}=-\frac{c_{I}}{2 D_{I}}<0$. Subsitusi nilai-nilai tersebut pada persamaan (9) akan memeberikan

$$
\begin{aligned}
& k_{1} \frac{c_{E}^{2}}{4 D_{E}}-k_{1} \frac{c_{E}^{2}}{2 D_{E}}+(\sigma-\gamma) k_{1}+\beta S^{*} k_{2}=0 \\
& k_{2} \frac{c_{I}^{2}}{4 D_{I}}-k_{2} \frac{c_{I}^{2}}{2 D_{I}}+\gamma k_{1}-\delta k_{2}=0
\end{aligned}
$$

Oleh karena persamaan (10) maka dapat diperoleh nilai dari kecepatan minimal pada kompartemen $E$ dan $I$ yaitu

$$
c_{E}=2 \sqrt{\frac{D_{E}\left(\beta S^{*} k_{2}-(\sigma-\gamma) k_{1}\right)}{k_{1}}}
$$




$$
c_{I}=2 \sqrt{\frac{D_{I}\left(\gamma k_{1}-\delta k_{2}\right)}{k_{2}}}
$$

Dimana dengan kecepatan minimal tersebut maka akan terjadi gelombang penyebaran di sekitar titik kesetimbangan endemik.

\section{Simulasi Numerik}

Simulasi model penyebaran virus ebola dilakukan dengan menggunakan software Matlab. Simulasi ini dilakukan terhadap titik kesetimbangan bebas penyakit $\left(E_{0}\right)$ dan titik kesetimbangan endemik $\left(E^{*}\right)$.

Pada simulasi model matematika dengan menggunakan Matlab, terdapat 4 subpopulasi, yakni subpopulasi yang rentan terhadap penyakit atau susceptible $(S)$, subpopulasi yang terjangkit penyakit atau exposed(E), subpopulasi yang terinfeksi penyakit atau infected(I), subpopulasi yang telah sembuh dari penyakit atau recovered $(R)$.

\section{Simulasi Model Matematika di $E_{0}$}

Simulasi di $E_{0}$ menggunakan syarat awal yakni untuk nilai awal subpopulasi yang rentan terhadap penyakit atau susceptible(S) adalah 20, subpopulasi yang exposed $(E)$ adalah 5 , subpopulasi yang terinfeksi penyakit atau infected(I) adalah 10, subpopulasi yang telah sembuh dari penyakit atau recovered $(R)$ adalah 2 .

Nilai-nilai parameter yang digunakan untuk simulasi di titik ekuilibrium bebas penyakit $E_{0}=\left(\frac{A}{\mu}, 0,0,0\right)$ adalah $A=1 ; \beta=0.005 ; \gamma=0.1 ; \mu=0.06$; $\delta=0.2$. Dari nilai-nilai parameter yang diberikan, diperoleh $R_{0}=\frac{\beta A}{\mu \delta}=0.42<1$.

Hasil simulasi di titik ekuilibrium bebas penyakit menggunakan Matlab diberikan pada Gambar 1.

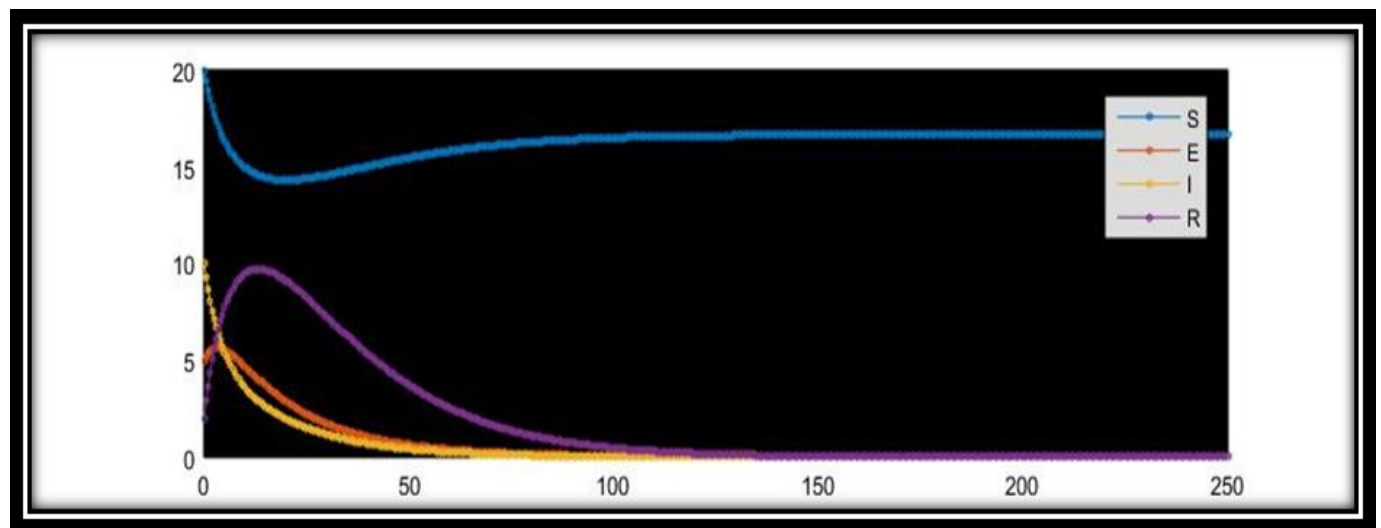

Gambar 1. Grafik banyak populasi terhadap waktu untuk titik ekuilibrium bebas penyakit saat $R_{0}<1$ dengan $S(0)=20, E(0)=5, I(0)=10, R(0)=2$.

Gambar 1 menunjukkan bahwa banyak subpopulasi yang rentan terhadap penyakit atau susceptible(S) mengalami penurunan sampai waktu(t) tertentu, hal itu terjadi karena sebagian individu ini memasuki subpopulasi exposed, dan mati secara alami. Pada subpopulasi exposed $(E)$ mengalami kenaikan sampai waktu(t) 
tertentu, hal itu terjadi karena sebagian individu pada subpopulasi yang rentan penyakit memasuki subpopulasi ini. Selanjutnya banyak subpopulasi yang terjangkit penyakit mengalami penurunan setelah waktu $(\mathrm{t})$ tertentu, hal itu terjadi karena sebagian individu pada subpopulasi ini memasuki subpopulasi terinfeksi penyakit. Pada subpopulasi yang terjangkit penyakit terlihat bahwa subpopulasi ini tidak akan mengalami perubahan pada waktu(t) tertentu. Pada keadaan tersebut, sistem berada dalam kondisi setimbang. Pada subpopulasi yang terjangkit penyakit, banyak subpopulasi ini akan mencapai nol pada saat waktu(t) tertentu dan konstan pada titik tersebut.

Pada subpopulasi yang terinfeksi penyakit atau infected(I) mengalami penurunan, hal itu terjadi karena sebagian individu pada subpopulasi ini memasuki subpopulasi yang telah sembuh dari penyakit, dan mati secara alami maupun mati akibat virus. Pada subpopulasi yang terinfeksi terlihat bahwa banyak subpopulasi ini tidak akan mengalami perubahan pada waktu(t) tertentu. Pada keadaan tersebut, sistem berada dalam kondisi setimbang. Pada subpopulasi yang terinfeksi, banyak subpopulasi akan mencapai nilai nol pada saat waktu(t) tertentu dan konstan pada titik tersebut.

Sedangkan pada subpopulasi yang telah sembuh dari penyakit atau recovered $(R)$ kenaikan sampai waktu(t) tertentu, hal itu terjadi karena sebagian individu pada subpopulasi yang terinfeksi penyakit memasuki subpopulasi ini. Selanjutnya banyak subpopulasi yang telah sembuh dari penyakit mengalami penurunan, hal itu terjadi karena subpopulasi ini mati secara alami. Pada subpopulasi yang telah sembuh dari penyakit terlihat bahwa banyak subpopulasi ini tidak akan mengalami perubahan pada waktu(t) tertentu. Pada keadaan tersebut, sistem berada dalam kondisi setimbang. Pada subpopulasi yang telah sembuh dari penyakit, banyak subpopulasi akan mencapai nilai nol pada saat waktu(t) tertentu dan konstan pada titik tersebut.

\section{Simulasi Model Matematika di $E^{*}$}

Simulasi di $E^{*}$ menggunakan syarat awal yakni untuk nilai awal subpopulasi yang rentan terhadap penyakit atau susceptible(S) adalah 20, subpopulasi yang terjangkit penyakit atau exposed $(E)$ adalah 5, subpopulasi yang terinfeksi penyakit atau infected(I) adalah 10, subpopulasi yang telah sembuh dari penyakit atau recovered $(R)$ adalah 2 .

Pada simulasi model matematika di $E^{*}$, parameter-parameter yang diubah adalah $\beta$. Untuk parameter $\beta$, nilai-nilai yang digunakan adalah $\beta=0.5$. nilainilai parameter yang digunakan untuk simulasi di titik ekuilibrium endemik $E^{*}=\left(\frac{\delta}{\beta}, \frac{\beta A-\mu \delta}{\beta \gamma}, \frac{\beta A-\mu \delta}{\beta \delta}, \frac{\beta A-\mu \delta}{\beta \mu}\right)$ adalah $A=1 ; \beta=0.05 ; \gamma=0.1 ; \mu=0.06$; $\delta=0.2$. Dari nilai-nilai parameter yang diberikan, diperoleh $R_{0}=\frac{\beta A}{\mu \delta}=4.2>1$.

Hasil simulasi di titik ekuilibrium endemik menggunakan Matlab diberikan pada Gambar 2.

380 BRILIANT: Jurnal Riset dan Konseptual Volume 5 Nomor 2, Mei 2020 


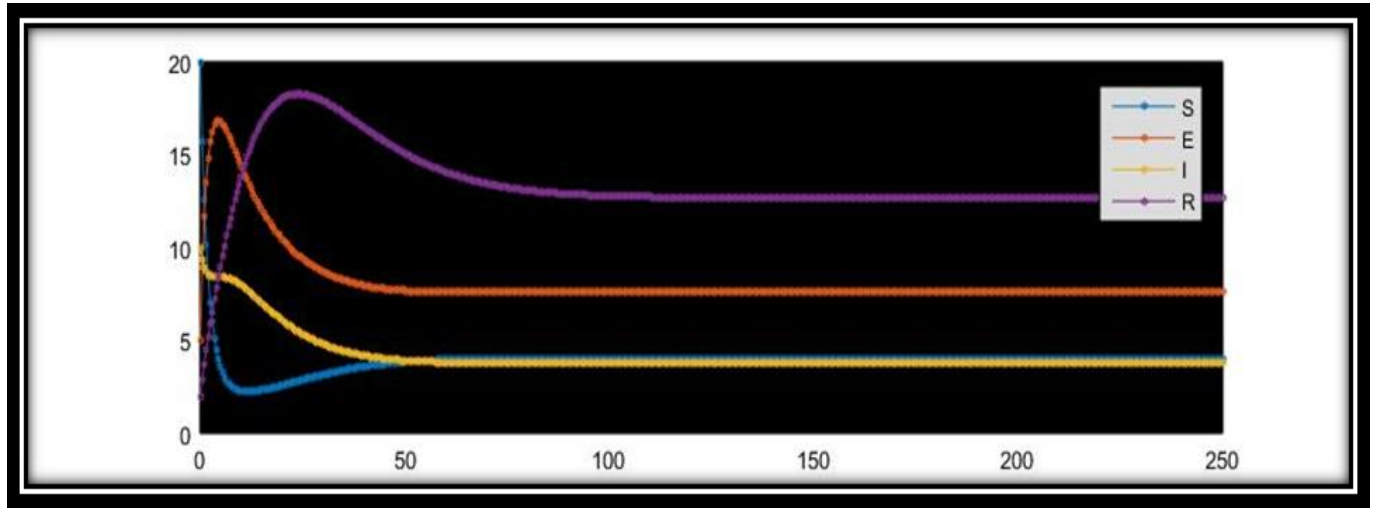

Gambar 2. Grafik banyak populasi terhadap waktu untuk titik ekuilibrium endemik saat $R_{0}>1$ dengan $S=20, E=5, I=10, R=2$.

Gambar 2 menunjukkan bahwa banyak subpopulasi yang rentan terhadap penyakit atau susceptible(S) mengalami penurunan sampai waktu(t) tertentu, hal itu terjadi karena sebagian individu ini memasuki subpopulasi yang terjangkit penyakit, dan mati secara alami. Setelah banyak subpopulasi yang rentan terhadap penyakit mulai naik setelah waktu(t) tertentu, hal itu terjadi karena adanya penambahan subpopulasi. Pada subpopulasi yang rentan terhadap penyakit terlihat bahwa subpopulasi ini tidak akan mengalami perubahan pada waktu(t) tertentu. Pada keadaan tersebut, sistem berada dalam kondisi setimbang. Pada subpopulasi yang rentan terhadap penyakit, berdasarkan hasil simulasi numerik banyak subpopulasi saat waktu(t) tertentu akan konstan pada titik tersebut.

Pada subpopulasi yang terjangkit penyakit atau exposed $(E)$ mengalami kenaikan sampai waktu(t) tertentu, hal itu terjadi karena sebagian individu pada subpopulasi yang rentan penyakit memasuki subpopulasi ini. Selanjutnya jumlah subpopulasi yang terjangkit penyakit mengalami penurunan setelah waktu(t) tertentu, hal itu terjadi karena sebagian individu pada subpopulasi ini memasuki subpopulasi terinfeksi penyakit. Pada subpopulasi yang terjangkit penyakit terlihat bahwa subpopulasi ini memiliki nilai konstan waktu(t) tertentu. Pada keadaan tersebut, sistem berada dalam kondisi setimbang. Pada subpopulasi yang terjangkit penyakit, banyak subpopulasi akan mencapai nol pada saat waktu(t) tertentu dan konstan pada titik tersebut.

Pada subpopulasi yang terinfeksi penyakit atau infected(I) mengalami penurunan, hal itu terjadi karena sebagian individu pada subpopulasi ini memasuki subpopulasi yang telah sembuh dari penyakit, dan mati secara alami maupun mati akibat virus. Sedangkan pada subpopulasi yang telah sembuh dari penyakit atau recovered $(R)$ kenaikan sampai waktu(t) tertentu, hal itu terjadi karena sebagian individu pada subpopulasi yang terinfeksi penyakit memasuki subpopulasi ini. Dalam hal ini jumlah individu $I$ dan $R$ memiliki nilai konstan dengan $t$ tertnetu dimana pada keadaan tersebut sistem berada dalam kondisi setimbang.

\section{KESIMPULAN}

Dari penjelasan yang telah diberikan, dapat disimpulkan bahwa:

- Jika nilai parameter $\beta$ diperbesar maka $S$ (susceptible) turun kemudian naik pada waktu tertentu, E(exposed) naik kemudian turun mendekati nol, 
$I($ infected) turun mendekati nol, dan $R$ (recovered) naik kemudian turun pada waktu tertentu.

- Semakin besar nilai parameter $\beta$, maka semakin besar pula nilai $R_{0}$, begitu juga sebaliknya. Semakin besar nilai parameter $\beta$, maka semakin kecil pula subpopulasi yang rentan penyakit $(S)$ dan terinfeksi penyakit $(I)$, tetapi semakin banyak yang terjangkit penyakit $(E)$ dan sembuh dari penyakit $(R)$, begitu juga sebaliknya.

- Model travelling wave pada titik kesetimbangan bebas penyakit yaitu persamaan (2) dan endemik (8) memiliki kecepatan minimal $c_{I}=2 \sqrt{\frac{D_{I}\left(\gamma k_{1}-\delta k_{2}\right)}{k_{2}}}$ pada kompartemen $I$. Dalam hal ini kecepatan minimal pada model travelling wave bebas penyakit (2) yaitu

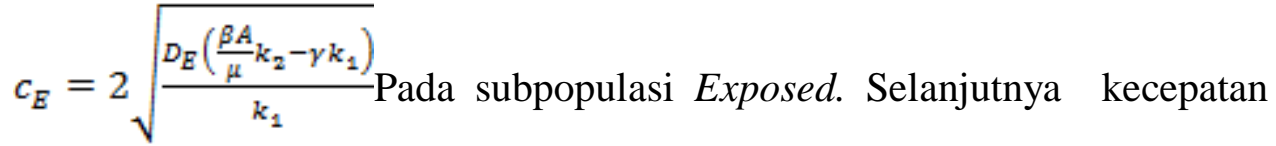
minimal yang diperoleh pada titik kesetimbangan endemik yaitu $c_{E}=2 \sqrt{\frac{D_{E}\left(\beta s^{*} k_{2}-(\sigma-\gamma) k_{1}\right)}{k_{1}}}$ yang berbeda dari model travelling wave pada titik bebas penyakit. Dalam hal ini, dengan kecepatan minimal tersebut maka pada model penyebaran virus ebola (1) dapat terjadi suatu gelombang penyebaran yang menginfeksi berbagai individu lainya.

\section{SARAN}

Pengamatan telah dilakukan pada model SEIR berkaitan dengan kestabilan yang terjadi pada model penyebaran virus ebola. Dalam hal ini pengamatan mengenai eksistensi travelling wave telah mendapatkan kesimpulan yang diinginkan. Namun pada penelitian ini tingkat kematian alami hanya terjadi pada inidividu susceptible dan recovery. Oleh karena itu untuk pengembangan penelitian selanjutnya, parameter kematian alami dapat ditambahkan pada individu exposed dan individu terinfeksi. Selanjutnya agar penelitian dapat berkembang jauh, dalam hal ini dapat dilakuan pengamatan pada model penyebaran virus ebola dengan memberikan asumsi tambahan bagi individu-individu yang keluar masuk dari suatu daerah (pengamatan dibagi kedalam dua populasi yang berbeda).

\section{DAFTAR RUJUKAN}

Haqqul, M. N., Hariyanto, \& Erna A. 2017. The Bifurcation and Traveling Wave Existence Analysis of Spreading Virus Ebola Model. Applied Mathematical Sciences, 11 (51): 2505-2525.

Hasrina. 2015. Model SIR (Susceptible, Infectious and Recovered) Pada Penyebaran Penyakit Tuberkulosis di Kota Makassar. Skripsi tidak diterbitkan. Makassar: Fakultas MIPA Universitas.Negeri Makassar.

Himawan, A., S. Budi W., \& Supriyono. 2017. Pemodelan Matematika Penyebaran Penyakit Ebola dengan Model Epidemi SIR Pada Populasi Manusia Tak Konstan Dengan Treatment. Unnes Journal of Mathematics, 6 (2): 154-167. 
Kousar, N., R. Mahmood, M. Ghalib. 2016. A Numerical Study of SIR Epidemic Model. International Journal of Sciences: Basic and Applied Research (IJSBAR), 25 (2): 354-363.

Liu, W. M. 1994. Criterion of Hopf Bifurcations without Using Eigenvalues. Journal of Mathematical Analysis and Applications. 182 (1), pp: 250-256.

Meyers, L., Frawley T., Goss S., \& Kang C. 2015. Ebola Virus Outbreak 2014: Clinical Review for Emergency Phsicians. Annals of Emergency Medicine, 65 (1), January 2015.

Muntoyimah, N., Widowati, YD. Sumanto. 2017. Analisis Kestabilan Model Penyebaran Virus Ebola. Jurnal Matematika, 20 (2): 103-110.

Nur, W., Nurul M. A. 2016. Solusi Numerik Model Umum Epidemik Susceptible, Infected, Recovered (SIR) dengan Menggunakan Metode Modified MilneSimpson. Jurnal Saintifik, 2 (2): 142-146.

Side, S., Sukarna, \& Arli M. U. 2017. Solusi Numerik Model SIR pada Penyebaran Penyakit Tuberkulosis dengan Metode Runge-Kutta, (Online), (http://eprints.unm.ac.id/5918/), diakses 2017.

Wiggins, S. (2003). Introduction to applied nonlinear dynamical systems and chaos (Vol. 2). New York: Springer. 